\title{
The Investigation of University Students' Forgiveness Levels in Terms of Self-compassion, Rumination and Personality Traits
}

\author{
Tuncay Oral ${ }^{1, *}$, Coskun Arslan ${ }^{2}$ \\ ${ }^{1}$ Department of Child Care and Youth Services, Pamukkale University, Turkey \\ ${ }^{2}$ Faculty of Ahmet Kelesoglu Education, Necmettin Erbakan University, Turkey
}

Copyright $\bigcirc 2017$ by authors, all rights reserved. Authors agree that this article remains permanently open access under the terms of the Creative Commons Attribution License 4.0 International License

\begin{abstract}
The aim of the study is to investigate forgiveness levels of university students in terms of self-compassion, rumination and personality traits. A descriptive-correlational was used and self-administered questionnaires were conducted in this study. Participants of the study were 840 university students (460 females, 380 males) from different faculties of Pamukkale University chosen by random cluster sampling method. In this study, forgiveness was measured with Heartland Forgiveness Scale; self-compassion was measured with Self-compassion Scale; rumination was measured with Rumination about an Interpersonal Offense Scale, and personality traits were measured with Adjective Based Personality Scale. To examine the predictive power of self-compassion, rumination and personality traits on forgiveness, hierarchical regression analysis was used. According to the results of the study, among university students, self-compassion and extraversion are both significant predictors of self-forgiveness. And also, both of them predict self-forgiveness positively. However, rumination, neuroticism, openness to experience, agreeableness and conscientiousness of personality traits do not predict self-forgiveness. Also according to results, among university students, self-compassion, rumination and extraversion, agreeableness and conscientiousness are significant predictors of forgiveness of others. While self-compassion, extraversion and agreeableness predict forgiveness of others positively, rumination and conscientiousness predict negatively. Implications of these findings are discussed within the context of literature.
\end{abstract}

Keywords Forgiveness, Self-compassion, Rumination, Personality Traits, University Students

\section{Introduction}

It is quite natural that a human being defined as a social creature experiences troubles and conflicts in her/his relations with others. Due to relevant troubles and conflicts, sometimes $\mathrm{s} /$ he hurts other people and sometimes is hurt by others. It is quite possible to come across too much information on what kind of incompatible reactions will be given when an individual was hurt, such as anger, revenge seeking, and also how these reactions are being processed. Yet, the studies on what will be the positive reactions in case of a same situation are very limited [7]. Until the beginning of twentieth century, researchers studying psychology had investigated negative emotions such as depression, anxiety, but did not pay adequate attention to studies related to positive emotions [45]. However, from the mid-1980s, the studies investigating how individuals can get benefit of their positive qualifications have risen with the momentum of the positive psychology. Forgiveness, which is accepted as a concept that can lead to positive emotions in "to hurt-to be hurt" cases in interpersonal relationships, has begun to be examined in this context in the recent 30 years [17, 64].

According to researches conducted on this topic, forgiveness plays a significant role in coping with negative feelings emerged after having problems and conflicts. For the person whose heart was broken, being able to forgive the offender is deeply related to realizing what the forgiveness is and what is not, and after that, it is related to being aware of the benefits of forgiving someone. Forgiveness is clarified as leaving negative emotions willingly such as anger, negative assessment, and on the other hand, it is described as promoting positive feelings such as love, mercy which are in fact undeserved by the one who harms unjustly [17, 43]. Nowadays, to understand the concept of forgiveness, some certain theoretical models have been put forward [17, 72]. These models are generally drawing attention forgiveness is a necessity for psychological health. According to Forgiveness Model of Enright et al. [17], forgiveness is a healthy process which helps individuals to overcome some emotions such as anger, disappointment and revenge. According to the Pyramid Model of Worthington [72], 
teaching clients to forgive others' faults is an important approach for them to struggle negative emotions and thoughts, to maintain situation of well-being and also to fix social relationships. Although each of these forgiveness models adopts an authentic approach on forgiveness, they have also some similar aspects. In terms of the researches which these models were tested in, if we look at those similarities generally, we can see that forgiveness has a negative relationship with some concepts such as pain, feeling of anger, aggression, rumination and perfectionism, but on the other side, it has a positive relationship with other concepts such as psychological health, reconciliation with offender, emphatic conception and giving up negative feelings [17, 35, 39, 72].

Giving up negative emotions, which is one of the notions related positively with forgiveness, can only be doable when individuals endeavour to relax themselves, to become tranquilized and to get rid of these negative feelings without doing any harm themselves. In order to be able to get rid of these negative emotions and to make life more liveable and understandable, individuals needs to acquire a high level of self-compassion. Therefore, coping with negative feelings will be easier for individuals who have high level of self-compassion [54]. Self-compassion can be defined as individual's treating her/himself conscientious and indulgent, instead of being rough, under negative circumstances, accepting negative incidents as a part of normal human life and developing a rational approach instead of focusing on negative aspects [46]. According to researches, it is found that self-compassion promotes psychological health and has a sedative effect against negative incidents occurred in life time [27]. The studies conducted by using the scale of self-compassion revealed that there is a negative relationship among forgiveness and depression, self-criticism, neuroticism, anxiety. However self-compassion is a positive relationship with several traits of psychological well-being such as self-acceptance, life satisfaction, self-respect, happiness and optimism [30].

The action of leaving of negative feelings, which brings individuals through to forgiveness process, is observed more individuals who have high level of self-compassion, but not people who have tendency to rumination generally [6]. The concept of rumination is defined as individual's thinking about negative mood, its symptoms, its probable reasons and its consequences, but never getting into action to solve that problem [51]. These people, in fact, are isolating themselves, always focusing on their own problems and negative moods created by these problems, since therefore; they believe that they are trying to find a way out. Actually, they may find some certain solutions, however they are not able to put in place these solutions. Therefore, individuals who have ruminative tendency focus on negative aspects of incidents more than others and live its consequences much longer [52]. Being engaged consistently with these thoughts and emotions related to the offense causes to negative feelings persist [41]. Besides, it is claimed that ruminative thinking has an important role in maintaining anger and revenge feelings, and thereby, failing in emotionally forgiving the other person [6]. When the literature is examined, it is seen that the concept of rumination which generally involves negative features is related negatively with some variables such as empathy [11], life satisfaction [73] and problem solving [70]; and positively with anger [57], ineffective coping [63], aggressive behaviour [12], experiential avoidance [50] and depression [11,22]. The concept of rumination about an interpersonal offense, which is adopted by this study, is defined and conceptualized by Wade et al. [68]. Rumination of interpersonal offense is clarified as repetitive thoughts accompanied with negative feelings against the person supposed to be the offender as a result of interpersonal offense, for instance being hard done by someone or suffered because of her/him [68].

Individuals living in the same society have diverging behaviours despite being exposed to similar environmental factors. For instance, some individuals might be able to think more ruminative, to be more merciful or indulgent rather than the others living in similar environment. If we seek the reason of this differentiation, we can come across a basic variable: the personality [25]. It is possible to describe the concept of personality as a consistent relationship type that the individual established with her/his internal and external environment and it serves to distinguish one person from the other people [14]. The concept of "distinguishing" here points out the whole of individual's sui generis and distinctive qualifications, not the common ones. The other concept of "consistency" underlines that the individual demonstrates similar behaviours under similar circumstances in the course of time [26].

Personality theoreticians have quite different considerations on which components of personality need to be examined. For instance, while psychoanalytic approach claims these concepts like consciousness, unconsciousness shape human behaviours; biological approach draws attention genetic tendencies. On the other hand, while humanistic approach pays attention to private responsibility and self-approval feeling, behavioural approach explains that all behaviours are the consequences of conditioning and expectations. Besides all, through the end of 1980's, two researchers Robert McCrae and Paul Costa have presented "the five-factor model" which is a common description of personality assessment in literature of personality psychology [18]. Five-factor model identifies five broad dimensions of personality and specific personality traits covered by these dimensions hierarchically. The fundamental assumption of the model is that individual differences can be coded in all languages all over the world; these differences will be reflected by means of words in those languages and, through these words, a classification including personality structures can be designed [59]. The researchers adopting this theory address to personality in five dimensions by using the data of different personalities. These five dimensions, which are neuroticism, extraversion, 
openness to experience, agreeableness and conscientiousness, have been acknowledged in many intercultural studies [19]. Dimension of neuroticism refers to personality traits like anxiety, stress, unease, and lack of confidence. Extraverted individuals are social, vigorous, cheerful, enthusiastic, optimistic and action-oriented. Spirited imagination, willingness to accept new ideas, multiple thinking and intellectual curiosity are among the traits covered by the dimension of openness to experience. Dimension of agreeableness can be explained with traits such as forgiveness, helpfulness, modesty, docility, mercy and reconciliatory. The people who have high level of agreeableness are altruistic and social people and love other people. Lastly, dimension of conscientiousness includes such traits as orderliness, responsibility, ambitiousness, cautiousness and discipline [18].

Briefly, in the light of aforementioned theoretical and experimental information, the main purposes of this study are to investigate those variables, which may play roles in the process of giving up, such as self-compassion, rumination about an interpersonal offense and personality traits, and also, to determine whether all they have influences on forgiveness or not.

\section{Method}

A descriptive-correlational research model was used and self-administered questionnaires were conducted in this study. Independent variables of the research were self-compassion, rumination about an interpersonal offense and five factor personality traits; the dependent variable of the research was forgiveness.

\subsection{Participants}

The data of the study were obtained from different faculties (education, engineering, economy) of Pamukkale University in Denizli/Turkey by random sampling method. The participants were 840 university students, including 460 girls and 380 boys in the 2015-2016 academic year. Data were gathered from voluntary participants of those students. The average age of the participants was 20.47 years.

\subsection{Instruments}

Heartland Forgiveness Scale: The scale was developed by Thompson et al. [64] to measure forgiveness level and it is 7-point Likert-type scale with 18 items. The scale is based on 3 sub-dimensions as well as self-forgiveness, forgiveness of others and forgiveness of situations. Each sub-scale involves 6 items. Translation and adaptation to Turkish was conducted by Bugay and Demir [10]. In order to test the applicability of the scale's 3-factors structured original version in Turkish example, confirmatory factor analyses has been conducted and it is detected that adaptive values are in sufficient level $\left(\mathrm{x}^{2} / \mathrm{sd}=2,33, \quad \mathrm{RMSEA}=.06, \quad \mathrm{GFI}=.92\right.$,
$\mathrm{CFI}=90$ ). For testing the reliability of Turkish version, Cronbach's alpha internal consistencies were calculated and reported as .64, .79, .76 for self-forgiveness, forgiveness of others and forgiveness of situations, respectively and .81 for total [10]. Only the sub-dimensions of self-forgiveness and forgiveness of others are used under this study.

Self-Compassion Scale: The scale's original version, which is developed by Neff [47] for measuring self-compassion, has 26 items and 6 sub-dimensions. Cronbach's alpha internal consistency of whole scale is calculated .92. Turkish reliability and validity of the scale was conducted by Deniz, Kesici and Sümer [15]. Differently from the original version, Turkish Self-Compassion Scale demonstrated one-dimensioned structure and 2 items which were calculated lower than 30 in total item correlation were omitted from the scale. Thereby, a scale consisting of 24 items in total was achieved. Additionally, Turkish Self-Compassion Scale's Cronbach's alpha internal consistency is calculated as .89 and test-retest reliability as .83. Regarding to criterion-related validity of Turkish Self-Compassion Scale, it is found that self-compassion correlated with self-respect as $\mathrm{r}=.62$; with life satisfaction $\mathrm{r}=.45$; with positive emotion $\mathrm{r}=.41$ and negative emotion $\mathrm{r}=$ -.48 [15].

Rumination About An Interpersonal Offense Scale: The scale was developed to investigate and measure repetitive thoughts causing negative feelings on the individual due to an interpersonal offense occurred in past [68]. The scale has 6 items and it is designed in 5-point Likert type. There is no item that needs to be scored oppositely and the scores obtained from the scale are in the range of 6-30. Higher scores demonstrate that the individual's level of rumination about an interpersonal offense is high. Translation and adaptation of the scale to Turkish was conducted by Oral and Arslan [53]. In the context of translation and adaptation studies, according to exploratory factor analysis, one-factored scale explains $62 \%$ of total variance. According to confirmatory factor analysis, the levels of adaptive values are determined as sufficient $\left(\mathrm{x}^{2} / \mathrm{sd}=3,82, \mathrm{p}<.001\right.$, $\mathrm{RMSEA}=.096, \mathrm{SRMR}=.04, \mathrm{GFI}=.97, \mathrm{AGFI}=.92, \mathrm{CFI}=98)$. In the context of reliability studies of the scale, total item correlation coefficients of the scale are in the range of .48 and .80. Scale's Cronbach's alpha internal consistency is calculated as .89 and test-retest correlation is found. [76, 53].

Adjective Based Personality Scale: This scale is developed by Bacanl, İlhan and Aslan [5] on the basis of five factor personality theory. Under the study, which was conducted to present a brief and practical tool to be used in personality researches, items are designed by using pairs of adjectives which are opposite to each other. There are 40 opposite pairs of adjectives in the scale such as "calm-nervous", "cheerless-cheerful". An application of the scale was conducted on university students during development process. Adjective Based Personality Scale has five sub-dimensions such as neuroticism, extraversion, openness to experience, agreeableness and 
conscientiousness. Factor analysis was conducted on the data obtained from 285 respondents to test the construct validity of the scale. According to results of the analyses, it is observed that five factors explain $52.63 \%$ of total variance. It is reported that internal consistency coefficients belonging to five factors vary in the range of .73 and .89 . Thus, when the findings of test-retest method are examined, it is found that test-retest correlations vary in the range of .68 and $.86[5]$.

\subsection{Data Analysis}

The correlation and multiple hierarchical regression analysis are used in the analysis of the data. The analyses are tested with the help of SPSS 16.0 package program with .01 and .05 levels of significance. Correlation coefficient technique was used to examine the relationship between forgiveness, self-compassion, rumination and five factor personality traits. Multiple hierarchical regression analysis was used to investigate whether self-compassion, rumination and five factor personality traits explain forgiveness.

\section{Results}

In this part of the research primarily, descriptive statistics and correlations among self-forgiveness, forgiveness of others, self-compassion, rumination about an interpersonal offense and five factor personalities are presented in Table 1. Subsequently, it is tested whether variables of self-compassion, rumination and personality traits predict self-forgiveness (in table 2), and forgiveness of others (Table $3)$.

Table 1. Descriptive Statistics, Cronbach Alphas and Correlations of the Variables

\begin{tabular}{|c|c|c|c|c|c|c|c|c|c|}
\hline Variables & 1 & 2 & 3 & 4 & 5 & 6 & 7 & 8 & 9 \\
\hline 1.Self-Forgiveness & - & & & & & & & & \\
\hline 2.Forgiveness of Others & $.17^{* *}$ & - & & & & & & & \\
\hline 3.Self-Compassion & $.58^{* *}$ & $.25^{* *}$ & - & & & & & & \\
\hline 4. Rumination & $-.30^{* *}$ & $-.18^{* *}$ & $-.48^{* *}$ & - & & & & & \\
\hline 5.Neuroticism & $-.34^{* *}$ & $-.18^{* *}$ & $-.51^{* *}$ & $.26^{* *}$ & - & & & & \\
\hline 6.Extraversion & $.23^{* *}$ & .05 & $.31^{* *}$ & $-.13^{* *}$ & $-.09^{*}$ & - & & & \\
\hline 7.Openness & $.15^{* *}$ & .06 & $.21^{* *}$ & $-.09^{*}$ & $-.10^{* *}$ & $.58^{* *}$ & & & \\
\hline 8.Agreeableness & $.19^{* *}$ & $.40^{* *}$ & $.26^{* *}$ & -.06 & $-.27^{* *}$ & $.22^{* *}$ & $38^{* *}$ & - & \\
\hline 9.Conscientiousness & $.16^{* *}$ & .01 & $.26^{* *}$ & $-.07^{*}$ & $-.08^{*}$ & $.38^{* *}$ & $.30^{* *}$ & $.39 *$ & - \\
\hline Mean & 28.39 & 25.05 & 75.21 & 20.80 & 25.32 & 43.78 & 41.68 & 47.50 & 36.12 \\
\hline Standard Deviation & 6.04 & 7.98 & 15.93 & 5.68 & 7.25 & 9.43 & 7.31 & 8.72 & 7.24 \\
\hline Cronbach Alpha & .70 & .82 & .91 & .87 & .70 & .85 & .76 & .80 & .80 \\
\hline
\end{tabular}

$* * \mathrm{p}<.01, * \mathrm{p}<.05$

Table 2. Hierarchical Linear Regression Analysis Results on Self-Forgiveness

\begin{tabular}{|c|c|c|c|c|c|c|c|c|c|}
\hline & & $\mathbf{R}$ & $\mathbf{R}^{2}$ & $\boldsymbol{R}_{C h}^{2}$ & $\mathbf{F}$ & B & $\beta$ & $\mathbf{t}$ & p \\
\hline \multirow{2}{*}{1} & Constant & \multirow{2}{*}{.58} & \multirow{2}{*}{.33} & \multirow{2}{*}{.33} & \multirow{2}{*}{414.56} & 11.99 & & 14.57 & $.00 * *$ \\
\hline & Self-Compassion & & & & & .22 & .58 & 20.36 & $.00 * *$ \\
\hline \multirow{3}{*}{2} & Constant & \multirow{3}{*}{.58} & \multirow{3}{*}{.33} & \multirow{3}{*}{.00} & \multirow{3}{*}{207.97} & 13.29 & & 9.38 & $.00 * *$ \\
\hline & Self-Compassion & & & & & .21 & .56 & 17.33 & $.00 * *$ \\
\hline & Rumination & & & & & -.04 & -.04 & -1.12 & .26 \\
\hline \multirow{8}{*}{3} & Constant & \multirow{8}{*}{.58} & \multirow{8}{*}{.34} & \multirow{8}{*}{.01} & \multirow{8}{*}{61.06} & 13.76 & & 6.59 & $.00 * *$ \\
\hline & Self-Compassion & & & & & .19 & .51 & 13.2 & $.00 * *$ \\
\hline & Rumination & & & & & -.04 & -.04 & -1.16 & .25 \\
\hline & Neuroticism & & & & & -.04 & -.05 & -1.56 & .12 \\
\hline & Extraversion & & & & & .05 & .08 & 2.15 & $.03 *$ \\
\hline & Openness & & & & & -.01 & -.02 & -.45 & .65 \\
\hline & Agreeableness & & & & & .03 & .04 & 1.06 & .29 \\
\hline & Conscientiousness & & & & & -.02 & -.02 & -.69 & .49 \\
\hline
\end{tabular}

${ }^{* *} \mathrm{p}<.01,{ }^{*} \mathrm{p}<.05$ 
Table 3. Hierarchical Linear Regression Analysis Results on Forgiveness of Others

\begin{tabular}{|c|c|c|c|c|c|c|c|c|c|}
\hline & & $\mathbf{R}$ & $\mathbf{R}^{2}$ & $R_{C h}^{2}$ & $\mathbf{F}$ & B & $\beta$ & $\mathbf{t}$ & $\mathbf{p}$ \\
\hline \multirow{2}{*}{1} & Constant & \multirow{2}{*}{.25} & \multirow{2}{*}{.06} & \multirow{2}{*}{.06} & \multirow{2}{*}{56.45} & 15.59 & & 12.11 & $.00 * *$ \\
\hline & Self-Compassion & & & & & .13 & .25 & 7.51 & $.00 * *$ \\
\hline \multirow{3}{*}{2} & Constant & \multirow{3}{*}{.26} & \multirow{3}{*}{.07} & \multirow{3}{*}{.01} & \multirow{3}{*}{30.67} & 19.47 & & 8.81 & $.00 * *$ \\
\hline & Self-Compassion & & & & & .11 & .21 & 5.57 & $.00 * *$ \\
\hline & Rumination & & & & & -.12 & -.08 & -2.16 & $.03 *$ \\
\hline \multirow{8}{*}{3} & Constant & \multirow{8}{*}{.50} & \multirow{8}{*}{.25} & \multirow{8}{*}{.18} & \multirow{8}{*}{38.78} & 12.80 & & 4.35 & $.00 * *$ \\
\hline & Self-Compassion & & & & & .10 & .20 & 4.76 & $.00 * *$ \\
\hline & Rumination & & & & & -.15 & -.11 & -3.05 & $.00 * *$ \\
\hline & Neuroticism & & & & & .05 & -.04 & 1.22 & .22 \\
\hline & Extraversion & & & & & .11 & .14 & 3.42 & $.00 * *$ \\
\hline & Openness & & & & & -.04 & -.03 & -.88 & .38 \\
\hline & Agreeableness & & & & & .42 & .46 & 12.85 & $.00 * *$ \\
\hline & Conscientiousness & & & & & -.18 & -.17 & -4.77 & $.00 * *$ \\
\hline
\end{tabular}

$* * \mathrm{p}<.01, * \mathrm{p}<.05$

Taking into account results of analysis in Table 1, it is seen that self-forgiveness was found to be significantly and positively correlated with self-compassion $(\mathrm{r}=.58, \mathrm{p}<.01)$, extraversion $(\mathrm{r}=.23, \mathrm{p}<.01)$, openness $(\mathrm{r}=.15, \mathrm{p}<.01)$, agreeableness $(\mathrm{r}=.19, \mathrm{p}<.01)$ and conscientiousness $(\mathrm{r}=.16$, $\mathrm{p}<.01$ ). Also it is seen that self-forgiveness was found to be significantly and negatively correlated with rumination $(\mathrm{r}=$ $-.30, \mathrm{p}<.01)$ and neuroticism $(\mathrm{r}=-.34, \mathrm{p}<.01)$.

Furthermore taking into account results of analysis in Table 1, it is seen that concept of forgiveness of others was found to be significantly and positively correlated with self-compassion $(\mathrm{r}=.25, \mathrm{p}<.01)$ and agreeableness $(\mathrm{r}=.40$, $\mathrm{p}<.01$ ). Also it is seen that concept of forgiveness of others was found to be significantly and negatively correlated with rumination $(r=-.18, p<.01)$ and neuroticism $(r=-.18, p<.01)$. Additionally, a significant correlation between forgiveness of others and extraversion $(\mathrm{r}=.05, \mathrm{p}>.05)$, openness $(\mathrm{r}=.06$, $\mathrm{p}>.05)$, conscientiousness $(\mathrm{r}=.01, \mathrm{p}>.05)$ was not found.

When Table 2 is examined, it was seen that self-compassion entered the model, developed to explain self-forgiveness, in first was seen to be significant in the model $\left(R^{2}=.33, p<.01\right)$. Rumination entered the model in second step was not found to be significant in the model $\left(R^{2}=.33, p>.01\right)$. Personality traits entered the model in third step was found to be significant in the model, $\left(R^{2}=.34, p<.01\right)$. The sub-dimension of personality traits; extraversion $(\beta=.08$, $p<.05$ ) was assumed to be significant.

When Table 3 is examined, it was seen that self-compassion entered the model, developed to explain forgiveness of others; in first was seen to be significant in the model $\left(R^{2}=.06, p<.01\right)$. Rumination entered the model in second step was found to be significant in the model $\left(R^{2}=.07\right.$, $p<.01)$. Personality traits entered the model in third step was found to be significant in the model, $\left(R^{2}=.25, p<.01\right)$. The sub-dimension of personality traits; extraversion $(\beta=.14$, $p<.01)$, agreeableness $(\beta=.46, p<.01)$ and conscientiousness ( $\beta=-.17, p<.01)$ was assumed to be significant.

\section{Discussion and Conclusions}

According to the results of the study, it is understood that, among university students, self-compassion and extraversion which is one of five factor personality traits are both significant predictors of self-forgiveness. And also, both of them predict self-forgiveness positively. However, rumination, neuroticism, openness to experience, agreeableness and conscientiousness of personality traits do not predict self-forgiveness. Therefore, it can be inferred that if the level of self-compassion and extraversion rises, the level of self-forgiveness will rise as well, among university students.

Under the studies conducted in literature, it is observed that self-forgiveness is related positively with self-respect [13], intellectual well-being [28], life satisfaction, positive feelings, cognitive flexibility [64], physical health [71] and empathy [23] but it is related negatively with anxiety and depression [64, 65], anger, suicidality [24], and neurotic symptoms [20]. It is expected but also significant result that the concept of self-compassion is predicting the concept of self-forgiveness which has a positive relationship with many positive variables and a negative relationship with many negative variables in literature. As a matter of fact, Enright et al. [17], during the work/action phase of self-forgiveness process model, describes the concept of compassion as individual's being aspirant to love her/himself despite offender's behaviours and her/his current pain. At the work/action phase of self-forgiveness process model, individual gains a different point of view by re-evaluating the situation, reviewing her/his own past; her/his psychological position at the time offense was occurred, and then, despite her/his mistakes, begins to love her/himself and to approach more indulgently. In the process of self-forgiveness, one's being tolerant against oneself, namely to be self-compassionate, is critical for the process. Thus, under the studies conducted by Asic1 and Karaca [4] 
and Mistler [44], a positive significant relationship was found between self-forgiveness and self-compassion. Likewise, a positive significant relationship was found between self-forgiveness and self-compassion also under this study, and additionally, it was observed that self-forgiveness is predicted by self-compassion positively. From this point of view, it can be said that the results of the study are in conformity with the literature.

Other than self-compassion, another predictor of self-forgiveness is extraversion which is one of the five factor personality traits. Extrovert individuals are generally vivacious, active, sociable, optimistic, happy and have positive feelings [40]. According to the literature, extraversion personality trait has a positive significant relationship with some variables such as patience [16], psychological well-being [58], self-compassion [2], satisfaction in intimate relationships [37] and positive perfectionism [66]; but a negative significant relationship with other variables such as anxiety, depression [29] and mortality risk [21]. It is not unexpected but also an important result that extraversion which has aforementioned features, predicts the concept of self-forgiveness which is a significant variable in terms of psychological well-being. Likewise, under the studies conducted by Ross et al. [56] and Ross et al. [55], it is found that there is a positive significant relationship between self-forgiveness and extraversion. And also under this study, it is observed that there is a positive significant relationship between self-forgiveness and extraversion, and that self-forgiveness is predicted positively by extraversion which is one of the five factor personality traits. From this perspective, it can be stated that the results of this study are in conformity with the literature.

According to results, among university students, self-compassion, rumination and extraversion, agreeableness and conscientiousness, which are among five factor personality traits, are significant predictors of forgiveness of others. While self-compassion, extraversion and agreeableness predict forgiveness of others positively, rumination about an interpersonal offense and conscientiousness predict negatively. At this point, it can be claimed that the level of forgiveness of others, among university students, will increase when their levels of selfcompassion, extraversion and agreeableness increase and also levels of rumination about an interpersonal offense and conscientiousness decrease.

Studies in the literature demonstrate that forgiveness of others has a positive relationship with life satisfaction, positive feelings, cognitive flexibility [64], psychological well-being [8], physical health [71], mental health [1] and empathy [34]. On the other hand, it has a negative relationship with negative feelings, anger, revenge, automatic hostile thoughts, anxiety [64], health problems [32] and depression $[60,65]$. It can be claimed that the concept of self-compassion's predicting the concept of forgiveness of others, which is accepted as a positive variable in terms of psychological health, is in conformity with the literature. Likewise, in work/action phase of forgiveness of others process model, Enright et al. [17] expresses the concept of compassion as being eager to approach to the process mercifully by re-considering the offense despite behaviours of the offender. In this phase, the individual gains different perspective by reassessing the whole process and starts to approach to the offender with sympathy despite all those mistakes. It is stated that individual's being indulgent against to offender is quite important for the process of forgiving others. Furthermore, under the studies conducted by As1c1 and Karaca [4], Neff and Pommier [48], Mistler [44], a positive significant relationship between forgiveness of others and self-compassion was found. Under this study also, a positive significant relationship between forgiveness of others and self-compassion is observed. Moreover, forgiveness of others is predicted by self-compassion in a positive way. Therefore, it can be asserted that this study is in conformity with the literature.

Except self-compassion, the other predictor among variables predicting forgiveness of others is the rumination about an interpersonal offense. When the literature is examined, it is detected that the concept of rumination which has generally negative features is related negatively with various variables such as empathy [11], life satisfaction [73] and problem solving [70]; and positively with such variables as anger [57], ineffective coping [63] and depression [11]. That the concept of rumination predicts the concept of forgiveness of others which is a significant variable in terms of psychological well-being is an expected situation but it can be evaluated as an important result as well. Likewise, in uncovering phase of forgiveness of others process model, Enright et al. [17] indicated that the situation of "being aware of one's thinking again and again about the offender's fault" is an important element for forgiving others. At this point, the individual who will forgive the offender cannot be able to get through to forgiveness phase, since s/he is thinking again and again about the existing negative situation. In forgiveness of others process model, individual takes a positive step by expanding her/his awareness. Martin and Tesser [38] describe the rumination as a repetitive thinking style even when the circumstances requiring thinking does not exist. Therefore, from the view point of this definition, it can be said that individual's action "thinking again and again" is a ruminative action in terms of forgiveness of others process model. Under the process model, individual notices that her/his action is ruminative and directs her/himself through to the process of forgiveness. Therefore, it can be stated that increasing awareness about the rumination is significant in terms of forgiveness of others process. Moreover, under the studies conducted by $[11,33,6,73$, 42], a significant relationship in opposite way between forgiveness of others and rumination was found. In other words, the level of forgiveness of others increases when the level of rumination decreases. And also under this study, it is observed that there is a significant relationship in 
opposite way between forgiveness of others and rumination and that forgiveness of others is predicted by rumination negatively. From this perspective, it can be said that the results of the study is in conformity with the literature.

Extraversion, which is one of the factors of five factor personality traits, is another predictor of forgiveness of others. Extrovert individuals are generally vivacious, active, sociable, optimistic, happy and people who have positive feelings [40]. In literature, extraversion personality trait has a positive significant relationship with some variables such as self-compassion [2], psychological well-being [58] and satisfaction in intimate relationships [37]; and has a negative significant relationship with other variables such as anxiety, depression [29] and mortality risk [21]. It is not unexpected but a significant result that extraversion trait which is covering aforementioned features predicts the concept of forgiveness of others which is an important variable in terms of psychological well-being. Furthermore, under the studies conducted by Ross et al. [56] Brose et al. [9] and Unterrainer et al. [67], it is found that there is a positive significant relationship between forgiveness of others and extraversion. As a result, it can be indicated that the results of the study are in conformity with the literature.

Another predictor of forgiveness of others is the agreeableness which is one of the five factor personality traits. It is observed that agreeable individuals are merciful, forgiver, respectful, trustworthy, polite, modest and soft-hearted. It is stated that those people in this dimension are not short-tempered, unreliable, rude, pessimist, combative and do not demonstrate narcissistic tendencies [40, 61]. It is reported that agreeable individuals have high level of psychological well-being and high level of satisfaction in intimate relationships $[37,58]$. It is an expected but significant result that agreeableness personality trait predicts the concept of forgiveness of others which is an important variable in terms of psychological well-being. Likewise, McCrae and Costa [40] claimed that agreeable individuals are merciful people. While identifying agreeableness personality trait, they have made similar explanations to the results of this study. Thus, under the studies conducted by Koutsos et al. [31], Neto [49], Brose et al. [9], Malinovic et al. [36], a positive significant relationship was found between forgiveness of others and agreeableness. In other words, it can be said that the level of forgiveness of others will increase, if the level of agreeableness increases. From this perspective, we can claim that the result of this study is in conformity with the literature.

The last variable predicting forgiveness of others is conscientiousness which is one of the factors of five factor personality traits. The individuals having conscientiousness personality trait are the people who are organized, disciplined, cautious, planned and perfectionism. Conscientiousness personality trait includes both fostering and hampering aspects. Fostering aspects are shown in achievement need and decisiveness; hampering aspects are shown in punctiliousness, excessive cautiousness and perfectionism $[40,61,66]$. However, a significant relationship cannot be found between dimensions of conscientiousness and forgiveness of others under this study. In literature, under the studies conducted by Neto [49], Brose et al. [9], Ashton et al. [3], Unterrainer et al. [67], Ross et al. [56], Walker and Gorsuch [69], any significant relationship can be found between conscientiousness and forgiveness of others, which it is such supportive as to the results of this study. Another result of this study is that the conscientiousness personality trait predicts the forgiveness of others negatively, when it is included into hierarchical linear multiple regression analysis with self-compassion, rumination and other personality traits. This result is not consistent with the literature. In literature, likewise in those studies mentioned above, any significant relationship can be found between conscientiousness and forgiveness of others and it is not ever mentioned that conscientiousness predicts forgiveness of others. In order to explain this situation, the study conducted by Ross et al. [56] in literature was examined. In this study, a significant relationship in opposite way was found between forgiveness of others and orderliness dimension which is a sub-dimension of conscientiousness personality trait. In another words, when orderliness increases, forgiveness of others decreases. Moreover, it is cited in a study conducted by Somer, Korkmaz and Tatar [62] that the people having conscientiousness personality trait are the people who comply with the rules and attach importance to orderliness. And also McCrae and Costa [40] reported that these individuals are organized, disciplined, planned and perfectionism. Moving from these studies, it might be considered that the individuals who are in the dimension of conscientiousness among five factor personality traits are organized, rule-bound, disciplined and perfectionism and this prevents them forgive an offense directed to them. Despite all these explanations, it seems rational to re-investigate in different sample groups whether conscientiousness personality trait predicts forgiveness of others negatively or not.

By depending on results of this study, some suggestions can be presented. The experts providing psychological consultation services to individuals or groups may come across some clients who cannot forgive themselves for their mistakes or who feel negative emotions, who behave negatively towards the offender because of being hurt by her/him and therefore who cannot forgive others. By depending on the finding of this study proving that self-forgiveness and others was predicted positively by self-compassion, experts, in course of psychological consultation process with groups or individually, may prompt their clients to increase their self-compassion levels. Additionally, under this study, it is found that individual's personality traits influence self-forgiveness and forgiveness of others processes. Moving from these results and information, in the course of designing psycho-education programs on self-forgiveness and forgiveness of others for 
university students, to organize some kind of events and workshops enabling them to explore their own personalities may be suggested.

\section{Acknowledgements}

1)This study was based on the first author's doctoral thesis directed by second author.

2)This study was supported by a grant from scientific research projects unit of Necmettin Erbakan University (Project Number: 161410006)

\section{REFERENCES}

[1] Akın, M., Özdevecioğlu, M., \& Ünlü, O. (2012). Örgütlerde intikam niyeti ve affetme eğiliminin çalışanların ruh sağlıkları ile ilişkisi. Amme İdaresi Dergisi, 45(1), 77-97.

[2] Arslan, C. (2016). Interpersonal problem solving, self-compassion and personality traits in university students. Educational Research and Reviews, 11(7), 474-481.

[3] Ashton, M. C., Paunonen, S. V., Helmes, E., \& Jackson, D. N. (1998). Kin altruism, reciprocal altruism, and the big five personality factors. Evolution and Human Behavior, 19(4), 243-255.

[4] Asıcı, E. \& Karaca, R. (2014). Öğretmen adaylarında affetme özelliği ve öz-duyarlık. The Journal Of Academic Social Science Studies, 27, 489-505.

[5] Bacanl1, H., İlhan, T. \& Aslan, S. (2009). Beş faktör kuramına dayalı bir kişilik ölçeğinin geliştirilmesi: Sıfatlara dayalı kişilik testi (SDKT). Türk Eğitim Bilimleri Dergisi, $7(2), 261-279$.

[6] Berry, J. W., Worthington, E. L., O'Connor, L. E., Parrott, L. ve Wade, N. G. (2005). Forgivingness, vengeful rumination, and affective traits. Journal of Personality, 73(1), 183-226.

[7] Bono, G. \& McCullough, M. E. (2006). Positive responses to benefit and harm: Bringing forgiveness and gratitude into cognitive psychotherapy. Journal of Cognitive Psychotherapy, 20(2), 147-158.

[8] Bono, G., McCullough, M. E. \& Root, L. M. (2008). Forgiveness, feeling connected to others, and well-being: Two longitudinal studies. Personality and Social Psychology Bulletin, 34(2), 182-195.

[9] Brose, L. A., Rye, M. S., Lutz-Zois, C. \& Ross, S. R. (2005). Forgiveness and personality traits. Personality and Individual Differences, 39(1), 35-46.

[10] Bugay, A. \& Demir, A. (2010). A Turkish version of Heartland Forgiveness Scale. Procedia-Social and Behavioral Sciences, 5, 1927-1931.

[11] Burnette, J. L., Davis, D. E., Green, J. D., Worthington, E. L. \& Bradfield, E. (2009). Insecure attachment and depressive symptoms: The mediating role of rumination, empathy and forgiveness. Personality and Individual Differences, 46, 276-280.
[12] Bushman, B. J. (2002). Does venting anger feed or extinguish the flame? Catharsis, rumination, distraction, anger, and aggressive responding. Personality and Social Psychology Bulletin, 28(6), 724-731.

[13] Coates, D. (1996). The correlations of forgiveness of self-forgiveness of others, and hostility, depression, anxiety, self-esteem, life-adaptation, and religiosity among female victims of domestic violence. Unpublished doctoral dissertation, California School of Professional Psychology, Fresno.

[14] Cüceloğlu, D. (2004). Yeniden insan insana (32. Edition). İstanbul: Remzi Kitabevi.

[15] Deniz, M., Kesici, Ş. \& Sümer, A. S. (2008). The validity and reliability of the Turkish version of the Self-Compassion Scale. Social Behavior and Personality, 36(9), 1151-1160.

[16] Eliüşük, A. (2014). Sabır eğiliminin öz-belirleme öz-anlayış ve kişilik özellikleri açısından incelenmesi. Unpublished doctoral dissertation. Necmettin Erbakan Üniversitesi, Konya.

[17] Enright, R. D. \& The Human Development Study Group (1996). Counseling within the forgiveness triad: On forgiving, receiving forgiveness, and self-forgiveness. Counseling and Values, 40(2), 107-126.

[18] Feist, J. \& Feist, G. J. (2008). Teories of personality (7. Edition). New York: McGraw Hill.

[19] Feldman, R. S. (2011). Understanding psychology (11. Edition). New York: McGraw Hill.

[20] Fisher, M. L. \& Exline, J. J. (2006). Self-forgiveness versus excusing: The roles of remorse, effort, and acceptance of responsibility. Self and Identity, 5(2), 127-146.

[21] Fry, P. S. \& Debats, D. L. (2009). Perfectionism and the five-factor personality traits as predictors of mortality in older adults. Journal of Health Psychology, 14(4), 513-524.

[22] Greenberg, S. T., Shepard, S. J., Chuick, C. D. \& Cochran, S. V. (2009). Clinical and personality features of depressed college males: An exploratory investigation. International Journal of Men's Health, 8(2), 169.

[23] Hall, J. H. \& Fincham, F. D. (2008). The temporal course of self-forgiveness. Journal of Social and Clinical Psychology, 27(2), 174.

[24] Hirsch, J. K., Webb, J. R. \& Jeglic, E. L. (2012). Forgiveness as a moderator of the association between anger expression and suicidal behaviour. Mental Health, Religion \& Culture, 15(3), 279-300.

[25] Hogan, R., Hogan, J. \& Roberts, B. W. (1996). Personality measurement and employment decisions: Questions and answers. American Psychologist, 51(5), 469.

[26] Inanç, B. Y. \& Yerlikaya, E. E. (2012). Kişilik kuramları (4. Edition). Ankara: Pegem Akademi Yayıncılık.

[27] Iskender, M. (2009). The relationship between self-compassion, self-efficacy, and control belief about learning in Turkish university students. Social Behavior and Personality, 37(5), 711-720.

[28] Jacinto, G. A. (2007). Caregivers negotiating self-forgiveness after the death of carereceivers diagnosed with alzheimer's disease. Dissertation Abstracts International, 68(5), 1-14. 
[29] Kim, S. E., Kim, H. N., Cho, J., Kwon, M. J., Chang Y., Ryu S., Shin, H. \& Kim, H. L. (2016). Direct and indirect effects of five factor personality and gender on depressive symptoms mediated by perceived stress. Plos One Journal, 11(4): e0154140. doi:10.1371/journal.pone.

[30] Kirkpatrick, K.L. (2005). Enhancing self-compassion using a gestalt two-chair intervention. Unpublished doctoral thesis, University of Texas, Austin.

[31] Koutsos, P., Wertheim, E. H. \& Kornblum, J. (2008). Paths to interpersonal forgiveness: The roles of personality, disposition to forgive and contextual factors in predicting forgiveness following a specific offence. Personality and Individual Differences, 44(2), 337-348.

[32] Lawler - Row, K. A., Hyatt - Edwards, L., Wuensch, K. L. \& Karremans, J. C. (2011). Forgiveness and health: The role of attachment. Personal Relationships, 18(2), 170-183.

[33] Lucas, T., Young, J. D., Zhdanova, L. \& Alexander, S. (2010). Self and other justice beliefs, impulsivity, rumination, and forgiveness: Justice beliefs can both prevent and promote forgiveness. Personality and Individual Differences, 49, 851-856.

[34] Macaskill, A., Maltby, J. \& Day, L. (2002). Forgiveness of self and others and emotional empathy. The Journal of Social Psychology, 142(5), 663-665.

[35] Malcolm, W. M. \& Greenberg, L. S. (2000). Forgiveness as a process of change in individual psychotherapy. In M. E. McCullough, K. I. Pargament ve C. E. Thoresen (Eds.), Forgiveness: Theory, research, and practice. New York: Guilford Press.

[36] Malinovic, A., Fink, A., Lewis, A. J. \& Unterrainer, H. F. (2016). Dimensions of religious/spiritual well-being in relation to personality and stress coping: Initial results from Bosnian young adults. Journal of Spirituality in Mental Health, 18(1), 43-54.

[37] Malouff, J. M., Thorsteinsson, E. B., Schutte, N. S., Bhullar, N. \& Rooke, S. E. (2010). The five-factor model of personality and relationship satisfaction of intimate partners: A meta-analysis. Journal of Research in Personality, 44(1), 124-127.

[38] Martin, L. L. \& Tesser, A. (1996). Some ruminative thoughts. In: R.S. Wyer (Eds.), Advances in social cognition. Mahwah: Lawrence Erlbaum Associates.

[39] McCann, R. A. (2009). The relationships between self-conscious emotions, perfectionism, and the forgiveness of the self and others. Unpublished doctoral thesis, Seattle Pacific University, Seattle.

[40] McCrae, R. R. \& Costa, P. T. (2003). Personality in adulthood: A Five-Factor theory perspective. New York: Guilford Press.

[41] McCullough, M. E. (2000). Forgiveness as human strength: Theory, measurement, and links to well-being. Journal of Social and Clinical Psychology, 19(1), 43.

[42] McCullough, M. E., Bono, G. \& Root, L. M. (2007). Rumination, emotion, and forgiveness: Three longitudinal studies. Journal of Personality and Social Psychology, 92(3), 490.
[43] McCullough, M. E., Pargament, K. I. \& Thoresen, C. E. (2000). The psychology of forgiveness: History, conceptual issues and overview. In M. E. McCullough, K. I. Pargament ve C. E. Thoresen (Eds.), Forgiveness: Theory, research and practice. New York: Guilford Press.

[44] Mistler, B. A. (2010). Forgiveness, perfectionism, and the role of self-compassion. Unpublished doctoral thesis, University of Florida, Gainesville.

[45] Myers, D. G. \& Diener, E. (1995). Who is happy? Psychological Science, 6(1), 10-19.

[46] Neff, K. (2003a). Self-compassion: An alternative conceptualization of a healthy attitude toward oneself. Self and Identity, 2(2), 85-101.

[47] Neff, K. D. (2003b). The development and validation of a scale to measure self-compassion. Self and Identity, 2(3), 223-250.

[48] Neff, K. D. \& Pommier, E. (2013). The relationship between self-compassion and other-focused concern among college undergraduates, community adults, and practicing meditators. Self and Identity, 12(2), 160-176.

[49] Neto, F. (2007). Forgiveness, personality and gratitude. Personality and Individual Differences, 43(8), 2313-2323.

[50] Neziroğlu, G. (2010). Ruminasyon, yaşantısal kaçınma ve problem çözme becerileri ile depresif belirtiler arasindaki ilişkilerin incelenmesi. Unpublished Master's Thesis, Hacettepe Üniversitesi, Ankara.

[51] Nolen-Hoeksema, S. (1987). Sex differences in unipolar depression: Evidence and theory. Psychological Bulletin, 101(2), 259.

[52] Nolen-Hoeksema, S. \& Morrow, J. (1991). A prospective study of depression and posttraumatic stress symptoms after a natural disaster: The 1989 Loma Prieta Earthquake. Journal of Personality and Social Psychology, 61(1), 115.

[53] Oral, T. \& Arslan, C. (2016). Kişilerarası hataya ilişkin ruminasyon ölçeği'nin Türkçeye uyarlama çalışması. I. International Academic Research Congress Abstract Book. Konya: Çizgi Kitabevi.

[54] Özyeşil, Z. (2011). Üniversite öğrencilerinin öz-anlayış düzeylerinin bilinçli farkındalık kişilik özellikleri ve bazı değişkenler açısından incelenmesi. Unpublished Doctoral Thesis, Selçuk Üniversitesi, Konya.

[55] Ross, S. R., Hertenstein, M. J. \& Wrobel, T. A. (2007). Maladaptive correlates of the failure to forgive self and others: Further evidence for a two-component model of forgiveness. Journal of Personality Assessment, 88(2), 158-167.

[56] Ross, S. R., Kendall, A. C., Matters, K. G., Wrobel, T. A. \& Rye, M. S. (2004). A personological examination of self-and other-forgiveness in the five factor model. Journal of Personality Assessment, 82(2), 207-214.

[57] Rusting, C. L. \& Nolen-Hoeksema, S. (1998). Regulating responses to anger: effects of rumination and distraction on angry mood. Journal of Personality and Social Psychology, 74(3), 790-803.

[58] Sarıcaoğlu, H. \& Arslan, C. (2013). An investigation into psychological well-being levels of higher education students with respect to personality traits and self-compassion. Educational Sciences: Theory and Practice, 13(4), 2097-2104. 
[59] Sevi, E. S. (2009). Psikobiyolojik kişilik modeli ve beş faktör kişilik kuramı: Mizaç ve karekter envanteri (TCI) ile beş faktör kişilik envanterinin (5FKE) karşılaştırılması. Unpublished Master's Thesis, Ege Üniversitesi, İzmir.

[60] Skoda, A. M. (2011). The relation between self-compassion, depression and forgiveness of other. Unpublished Master's Thesis, University of Dayton, Ohio.

[61] Somer, O. (1998). Türkçede kişilik özelliği tanımlayan sıfatların yapısı ve beş faktör modeli. Türk Psikoloji Dergisi, 13(42), 17-32.

[62] Somer, O., Korkmaz, M. \& Tatar, A. (2002). Beş Faktör Kişilik Envanteri'nin geliştirilmesi-I: Ölçek ve alt ölçeklerin oluşturulması. Türk Psikoloji Dergisi, 17(49), 21-33.

[63] Stöber, J. (2003). Self - pity: Exploring the links to personality, control beliefs and anger. Journal of Personality, $71(2), 183-220$.

[64] Thompson, L. Y., Snyder, C. R., Hoffman, L., Michael, S. T., Rasmussen, H. N., Billings, L. S. \& Roberts, D. E. (2005). Dispositional forgiveness of self, others, and situations. Journal of Personality, 73(2), 313-360.

[65] Toussaint, L. L., Williams, D. R., Musick, M. A. \& Everson-Rose, S. A. (2008). The association of forgiveness and 12-month prevalence of major depressive episode: Gender differences in a probability sample of US adults. Mental Health, Religion and Culture, 11(5), 485-500.

[66] Ulu, İ. P. (2007). An investigation of adaptive and maladaptive dimensions of perfectionism in relation to adult attachment and big five personality traits. Unpublished Doctoral Thesis, Ortadoğu Teknik Üniversitesi, Ankara.
[67] Unterrainer, H. F., Ladenhauf, K. H., Moazedi, M. L., Wallner-Liebmann, S. J. \& Fink, A. (2010). Dimensions of religious/spiritual well-being and their relation to personality and psychological well-being. Personality and Individual Differences, 49(3), 192-197.

[68] Wade, N. G., Vogel, D. L., Liao, K. Y. H. \& Goldman, D. B. (2008). Measuring state-specific rumination: Development of the rumination about an interpersonal offense scale. Journal of Counseling Psychology, 55(3), 419-426.

[69] Walker, D. F. \& Gorsuch, R. L. (2002). Forgiveness within the big five personality model. Personality and Individual Differences, 32(7), 1127-1137.

[70] Ward, A., Lyubomirsky, S., Sousa, L. \& Nolen-Hoeksema, S. (2003). Can't quite commit: Rumination and uncertainty. Personality and Social Psychology Bulletin, 29(1), 96-107.

[71] Wilson, T., Milosevic, A., Carroll, M., Hart, K. \& Hibbard, S. (2008). Physical health status in relation to self-forgiveness and other-forgiveness in healthy college students. Journal of Health Psychology, 13(6), 798-803.

[72] Worthington, E. L. (1998). The pyramid model of forgiveness: Some interdisciplinary speculations about unforgiveness and the promotion of forgiveness. In E. L. Worthington (Eds.), Dimensions of forgiveness: Psychological research and theological perspectives. Philadelphia: Templeton Foundation Press.

[73] Ysseldyk, R., Matheson, K. \& Anisman, H. (2007). Rumination: Bridging a gap between forgivingness, vengefulness, and psychological health. Personality and Individual Differences, 42(8), 1573-1584. 